\title{
SCS123 Pérola: A Brazilian Rice Variety for Risotto
}

\author{
Ester Wickert*, Adriana Pereira, Alexander de Andrade, Fabiana Schmidt, \\ Klaus Konrad Scheuermann, Rubens Marschalek, José Alberto Noldin, Gabriela Neves Martins, \\ Eduardo Hickel, Marcos Lima Campos do Vale, Laerte Reis Terres
}

Agricultural Research and Rural Extension Company of Santa Catarina (EPAGRI), Itajaí Experimental Station, Itajaí, Brazil

Email: *esterwickert@epagri.sc.gov.br, eei@epagri.sc.gov.br

How to cite this paper: Wickert, E., Pereira, A., de Andrade, A., Schmidt, F., Scheuermann, K.K., Marschalek, R., Noldin, J.A., Martins, G.N., Hickel, E., do Vale, M.L.C. and Terres, L.R. (2018) SCS123 Pérola: A Brazilian Rice Variety for Risotto. Agricultural Sciences, 9, 1589-1600. https://doi.org/10.4236/as.2018.912111

Received: November 1, 2018

Accepted: December 15, 2018

Published: December 18, 2018

Copyright $\odot 2018$ by authors and Scientific Research Publishing Inc. This work is licensed under the Creative Commons Attribution International License (CC BY 4.0).

http://creativecommons.org/licenses/by/4.0/

\begin{abstract}
Specialty rices can present differences in some aspects related to grain pericarp color, shape, size, amylose content or aroma. Most of these rice types are related to cultural traditions and ceremonies, and some of them have also different nutritional value. As a specific market, the economic values of these grains are also higher than common milled rice. Santa Catarina State has the ideal conditions to produce specialty rices. The objective of this work was to develop a rice cultivar with special attributes for the well-appreciated risotto. Two rice lines were combined, evaluated and selected during ten years for characteristics related to Italian food. One line was selected and becomes the new rice variety SCS123 Pérola, developed to attend the economically important specialty rices market of Italian food, specifically the risotto. Experimental tests performed with this variety showed that it can be recommended to all rice-producing regions of Santa Catarina State, Brazil. Cooking tests showed that the grains are appropriated for risotto.
\end{abstract}

\section{Keywords}

Agriculture, Rice Production, Oryza sativa, Rice Breeding, Specialty Rices

\section{Introduction}

Rice is a staple food in many countries, notably India, China and Japan [1] [2] [3] [4]. In Brazil, rice is a very important food as a part of a traditional dish called rice and beans [5] that have wide acceptability throughout the country and is consumed almost every day by Brazilians. Brazilian consumers mostly prefer milled rice grains with long and thin shape, translucent and without any type of spots, with intermediate to high amylose content. Because of this, about 
$80 \%-85 \%$ of the Brazilian rice production attends this market request.

But in recent years, an increased number of consumers have tried new rice types mainly due to the culinary TV shows and social medias that had promoted a market segment of these specialty rices [4] [6]. In Brazil, the most representative is the niche of rice grains for Italian dishes, notably rice grains like the well-known "Arborio" and "Carnaroli". Brazilians are larger consumers of Italian dishes as part of the cultural traditions associated with the immigration.

"Arborio" and "Carnaroli" rice types are the most known and used to elaborate the well-appreciated "risotto". Therefore, "risotto" requires specific round shaped rice grains with porosity for absorb flavor and ability to liberate amylose to give the final creamy characteristic. At the end of cooking, the grains must preserve its shape, being flavored with the added savor, and fluffy with the inside part of the kernel more hard at eating time.

Despite having high rice production of traditional milled and parboiled rice, Brazil imports most of the specialty rice grains. This also occurs with rice for Italian dishes. Only in recent years, efforts were done in order to develop a rice cultivar adapted to Brazilian rice production areas, more specifically to Santa Catarina Sate (SC).

Santa Catarina is a traditional rice producer of long-shaped grains. Most of the rice area in SC is cultivated by pre-germinated system that results on an average yield of $8000 \mathrm{~kg} \cdot \mathrm{ha}^{-1}$ and most of the production is then parboiled by local industries and market in the country.

Despite having an established rice production chain in Santa Catarina with Research and Extension done by Epagri, seed producers, grain producers and industries, the establishment of a new specialty rice grain supply chain needs firstly to have available cultivars and seeds adapted to the production system.

Epagri has carried out a breeding research project entitled Specialty Rices with the objective to develop varieties adapted to soil and climate conditions of Santa Catarina for pigmented grains, low amylose (grains for Japanese and Italian dishes) and aromatic grains.

So, the objective of this work was develop a rice variety with agronomical traits, grain shape, amylose content and sensory attributes appropriated to Italian dishes as the risotto.

\section{Material and Methods}

\subsection{Pedigree and Breeding Method}

A hybridization of an Oryza glaberrima line (CNA 10709-HC72B1578) with the line SC 213 (elite-line from Epagri's Germplasm Bank) was done in 2008 and the obtained seeds originated $F_{1}$ plants in the following year. High genetic variability was displayed by $\mathrm{F}_{2}$ plant populations, allowing phenotypic selection for agronomical interesting traits, mainly as grain and plant type, tillering, plant height, number of grain per panicle, and for grain shape. Seeds from the selected plants formed $\mathrm{F}_{3}$ generation. The same selection procedure was carried out until the $\mathrm{F}_{6}$ 
generation (during 2014 growing season). From 2010 till 2013, the segregant populations were conducted in the field and plants were selected every year. A few lines were selected in 2013 and subsequently evaluated for yield, resistance to diseases, lodging and seed shattering. Because of the segregation observed in some of these populations, one more selecting cycle was added (F6 on year 2014). Three lines were identified in 2014 growing season as promising and were named SC 828, SC 829 and SC 830. These lines were evaluated in 2015 and 2016 for agronomical traits. Lines were conducted to assessments in larger plots (60 $\mathrm{m}^{2}$ ), in comparison with standard cultivars used in the region. At this point, uniformity, yield performance, lodging resistance and blast resistance were observed and measured.

\subsection{Field Performance}

Lines SC 828, SC 829 and SC 830 were evaluated for its performance at the field. The lines were phenotypically described for several traits (Table 1), according the descriptors recommended for rice culture [7]. The varieties SCS116 Satoru (conventional) and Empasc 104 (aromatic) were included as controls. These were used because at that time in Brazil there was not registered specific rice varieties for risotto. Despite the absence of registered Italian type rice variety by

Table 1. Agronomic and phenotypic characteristics of the new cultivar SCS123 Pérola, evaluated in the VCU trials (Itajaí, Araranguá and Lontras) in 2015-16 and 2016-17 growing season.

\begin{tabular}{cc}
\hline Plant trait & SCS123 Pérola \\
\hline Leaf color & Green \\
Leaf pubescence & Medium \\
Flag leaf angle & Upright \\
Tillering & Medium \\
Cycle to maturity & 135 - 144 days \\
Plant height & 111 cm \\
Lodging & Moderate \\
Resistance to blast & Moderate \\
Iron toxicity tolerance & Moderate \\
Pericarp color & White \\
Glumella color & Gold \\
Apex color at maturity & Yellow \\
Awns & Absent \\
Shattering & Intermediate \\
Weight (g/1000 seeds) & 30.79 \\
Chalky grains (\%) & 29.81 \\
Chalky área (\%) & 29.38 \\
\hline & \\
\hline & \\
\hline
\end{tabular}


MAPA (Brazilian Ministry of Agriculture, Livestock and Supply) in Brazil, it was used a traditional Carnaroli variety for comparison. The experiments were carried during 2015-16 and 2016-17 growing seasons representing the VCU (Value for Cultivation and Use) trials during two years on three different locations on Santa Catarina State. The VCU trials were done at Lontras $\left(27^{\circ} 09^{\prime} 58^{\prime \prime S}, 49^{\circ} 32^{\prime} 31^{\prime \prime} \mathrm{W}\right)$, Araranguá $\left(28^{\circ} 56^{\prime} 05^{\prime \prime} \mathrm{S}, 49^{\circ} 29^{\prime} 09^{\prime \prime} \mathrm{W}\right)$ and Itajaí $\left(26^{\circ} 54^{\prime} 28^{\prime \prime S}, 48^{\circ} 39^{\prime} 43^{\prime \prime W}\right)$ according recommendations of MAPA in order to register and protect the new variety. All these regions are classified according Köppen-Geiger as Cfa climate conditions. On these trials, uniformity, yield performance, grain pericarp color, lodging resistance and blast resistance were evaluated. Based on yield performance at the three locations allied with its desirable agronomic traits, one line was released as a new variety.

\subsection{Line Identification and Genotyping}

At the end of the performance tests, the line SC 829 was named SCS123 Pérola. Plants obtained from genetic seeds were used to provide the DNA identification by a panel of SSR markers recommended for this purpose by Gramene (http://www.gramene.org/, list of used primers on Table 2). Leaf samples were collected from 120 individual plants. DNA analysis was performed according WEISING [8]. The new variety was released and recommended in 2018 as a new rice variety for specialty rice market, mainly for Italian dishes like risotto.

\subsection{Grain Characteristics}

During the final experimental field trials, grain sample of each line was evaluated for parameters like size and milling performance. Size measures were done using an Image Rice Grain Scanner (Selgron) at Epagri's Rice Breeding Laboratory. Milling tests were done using laboratory mills to determine the proportion of broken and whole grains. Lines SC 828 , SC 829 and SC 830 were evaluated at industrial quality laboratories for its characteristics like pericarp color, chalk, and aroma, appearance before and after cooking, all of them in comparison with traditional Carnaroli variety. These tests together with field performance helped to decide what line would be the future cultivar. Later, grains of line SC 829 (SCS123 Pérola) were also submitted to risotto cooking tests in order to evaluate if its characteristics like appearance, aroma and taste also comparing with traditional Carnaroli variety. Later, different cookers and chefs tested SCS123 Pérola with their own risotto recipes.

\section{Results}

\subsection{Performance of SCS123 Pérola at the Field}

SCS123 Pérola presents a modern plant type with a cycle varying from 135 - 144 days, from emergence to maturity, and erect and hairy leaves (Figure 1). This cultivar presents good tolerance to lodging, a trait considered essential for the 
Table 2. SSR markers used for genotyping SCS123 Pérola, chromosome location, respective $\mathrm{F}$ and $\mathrm{R}$ sequences and total length of obtained allele fragments.

\begin{tabular}{|c|c|c|c|c|}
\hline SSR marker & Chr & Frontal (F) e Reverse (R) Sequences & $\begin{array}{c}\text { Melting } \\
\text { Temperature }\left({ }^{\circ} \mathrm{C}\right)\end{array}$ & $\begin{array}{l}\text { Fragment } \\
\text { lenght }(\mathrm{pb})\end{array}$ \\
\hline \multirow[t]{2}{*}{ RM-038 } & 8 & F-ACGAGCTCTCGATCAGCCTA & & 246 \\
\hline & & R-TCGGTCTCCATGTCCCAC & 56 & \\
\hline \multirow[t]{2}{*}{ RM-124 } & 4 & F-ATCGTCTGCGTTGCGGCTGCTG & & 269 \\
\hline & & R-CATGGATCACCGAGCTCCCCCC & 56 & \\
\hline \multirow[t]{2}{*}{ RM-125 } & 7 & F-ATCAGCAGCCATGGCAGCGACC & & 147 \\
\hline & & R-AGGGGATCATGTGCCGAAGGCC & 56 & \\
\hline \multirow[t]{2}{*}{ RM-133 } & 6 & F-TTGGATTGTTTTGCTGGCTCGC & & 228 \\
\hline & & R-GGAACACGGGGTCGGAAGCGAC & 56 & \\
\hline \multirow[t]{2}{*}{ RM-204 } & 6 & F-GCTAGCCATGCTCTCGTACC & & 104 \\
\hline & & R-GTGACTGACTTGGTCATAGGG & 56 & \\
\hline \multirow[t]{2}{*}{ RM-207 } & 2 & F-CACCTCATCCTCGTAACGCC & & 129 \\
\hline & & R-CCATTCGTGAGAAGATCTGA & 56 & \\
\hline \multirow[t]{2}{*}{ RM-215 } & 9 & F-CAAAATGGAGCAGCAAGAGC & & 148 \\
\hline & & R-TGAGCACСТCСТTCTCTGTAG & 56 & \\
\hline \multirow[t]{2}{*}{ RM-224 } & 11 & F-ATCGATCGATCTTCACGAGG & & 156 \\
\hline & & R-TGCTATAAAAGGCATTCGGG & 56 & \\
\hline \multirow[t]{2}{*}{ RM-237 } & 1 & F-CAAATCCCGACTGCTGTCC & & 132 \\
\hline & & R-GGGAAGAGAGCACTACAGC & 56 & \\
\hline \multirow[t]{2}{*}{ RM-247 } & 12 & F-CATATGGTTTTGACAAAGCG & & 134 \\
\hline & & R-TAGTGCCGATCGATGTAACG & 56 & \\
\hline \multirow[t]{2}{*}{ RM-248 } & 7 & F-GTAGCCTAGCATGGTGCATG & & 103 \\
\hline & & R-TCCTTGTGAAATCTGGTCCC & 56 & \\
\hline \multirow[t]{2}{*}{ RM-277 } & 12 & F-CGGTCAAATCATCACCTGAC & & 118 \\
\hline & & R-CAAGGCTTGCAAGGGAAG & 56 & \\
\hline \multirow[t]{2}{*}{ RM-283 } & 1 & F-GTCTACATGTACCCTTGTTGGG & & 155 \\
\hline & & R-CGGCATGAGAGTCTGTGATG & 56 & \\
\hline \multirow[t]{2}{*}{ RM-287 } & 11 & F-TTCCСTGTTAAGAGAGAAATC & & 113 \\
\hline & & R-GTGTATTTGGTGAAAGCAAC & 56 & \\
\hline \multirow[t]{2}{*}{ RM-316 } & 9 & F-CTAGTTGGGCATACGATGGC & & 200 \\
\hline & & R-ACGCTTATATGTTACGTCAAC & 56 & \\
\hline \multirow[t]{2}{*}{ RM-338 } & 3 & F-CACAGGAGCAGGAGAAGAGC & & 181 \\
\hline & & R-GGCAAACCGATCACTCAGTC & 56 & \\
\hline \multirow[t]{2}{*}{ RM-413 } & 5 & F-GGCGATTCTTGGATGAAGAG & & 101 \\
\hline & & R-TCCCCACCAATCTTGTCTTC & 56 & \\
\hline
\end{tabular}




\begin{tabular}{|c|c|c|c|c|}
\hline Continued & & & & \\
\hline RM-433 & 8 & F-TGCGCTGAACTAAACACAGC & & 229 \\
\hline & & R-AGACAAACCTGGCCATTCAC & 56 & \\
\hline $\mathrm{RM}-447$ & 8 & F-CCCTTGTGCTGTCTCCTCTC & & 122 \\
\hline & & R-ACGGGCTTCTTCTCCTTCTC & 56 & \\
\hline RM-452 & 2 & F-CTGATCGAGAGCGTTAAGGG & & 206 \\
\hline & & R-GGGATCAAACCACGTTTCTG & 56 & \\
\hline RM-484 & 10 & F-TCTСССТССТСАССАТТGTC & & 295 \\
\hline & & R-TGCTGCCCTCTCTCTCTCTC & 56 & \\
\hline RM-507 & 5 & F-CTTAAGCTCCAGC CGAAATG & & 258 \\
\hline & & R-CTCACCCTCATCATCGCC & 56 & \\
\hline RM-514 & 3 & F-AGATTGATCTCCCATTCCСC & & 249 \\
\hline & & R-CACGAGCATATTACTAGTGG & 56 & \\
\hline RM-536 & 11 & F-TCTCTCCTCTTGTTTGGCTC & & 234 \\
\hline & & R-ACACACCAACACGACCACAC & 56 & \\
\hline
\end{tabular}

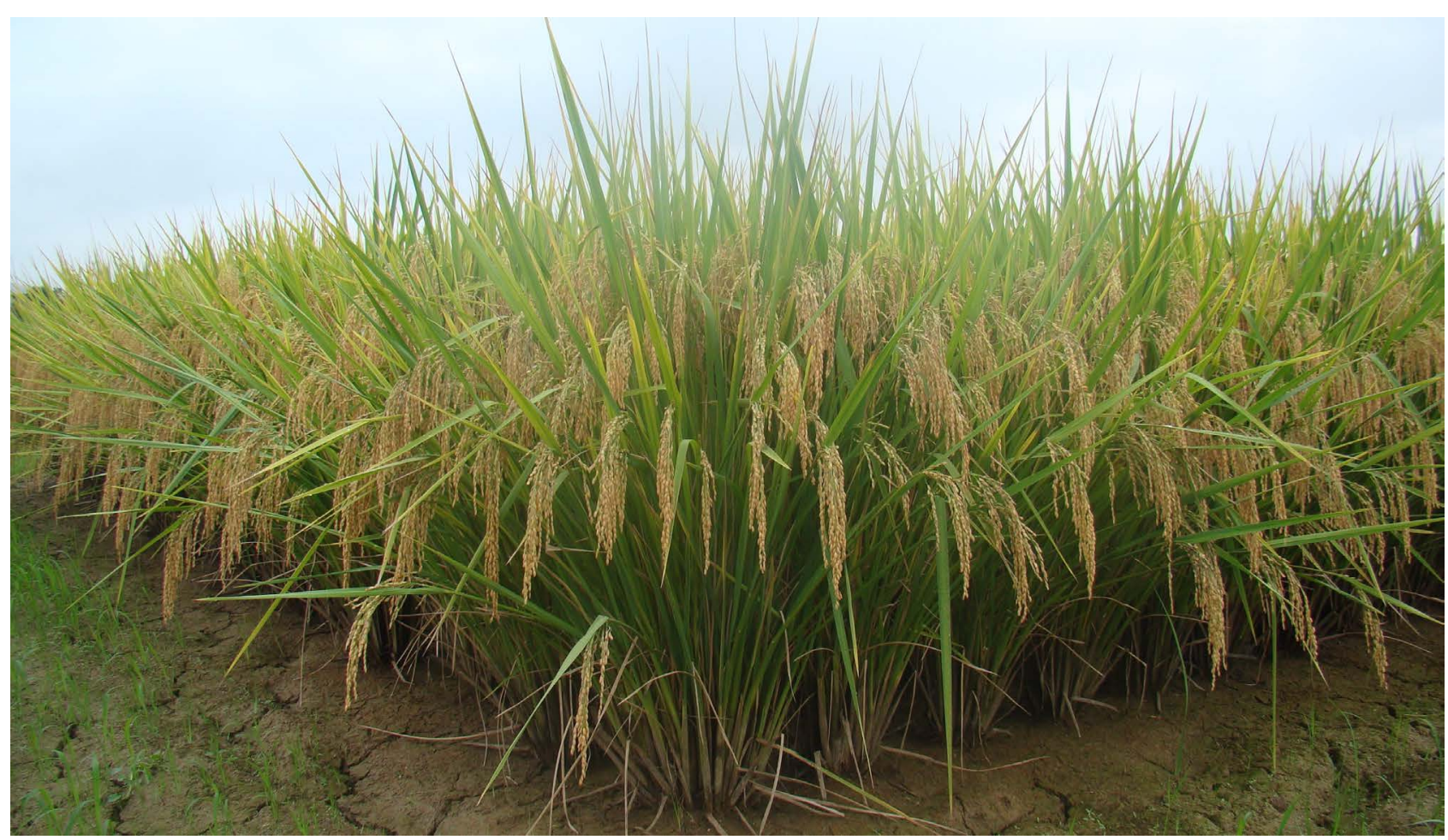

Figure 1. SCS123 Pérola on seeds production field-morphological plant aspects.

water-seeding system used in Santa Catarina and part of Rio Grande do Sul. It has also low seed shattering and moderate susceptibility to iron toxicity and blast. SCS123 Pérola presented excellent yield in regional trials (Itajaí, Araranguá, and Lontras) with an average of $10,182 \mathrm{~kg} \cdot \mathrm{ha}^{-1}$ (Table 3 ). The productivity was consistently higher than the control, a traditional Carnaroli variety, which 
presented an average yield of $3218 \mathrm{~kg} \cdot \mathrm{ha}^{-1}$.

\subsection{Line Identification and Genotyping}

The line SC 829 was selected to be cultivar and received the name SCS123 Pérola The cultivar name "Pérola" was due to its grain shape as a pearl and its white endosperm color. Twenty-four SSR markers were used for SCS123 Pérola genotyping and RM 484 presented an exclusive allele able to discriminate this cultivar.

\subsection{Grain Characteristics}

The grains of SCS123 Pérola present an L/W ratio of 2.46 with a rounded shape (Table 4, Figure 2 and Figure 3). The milling total yield for this rice was considered appropriated, with a total value of $70.8 \%$ and $63.03 \%$ of whole grain (Table 4). This variety presents medium percentage of amylose content, as is required for cooking a creamy dish with soft grains. Cooking risotto tests showed that SCS123 Pérola presents all required characteristics for the Italian dish. Cooking tests done by different cookers under various recipes using different ingredients approved the SCS123 Pérola grains as adequate for cooking a precious risotto (Figure 4).

\section{Discussion}

Epagri's Breeding Specialty Rices Project goal is to develop varieties adapted to

Table 3. Average grain yield $\left(\mathrm{kg} \cdot \mathrm{ha}^{-1}\right)$ of SCS123 Pérola, SCS 116 Satoru Carnaroli, Empasc 104, in the VCU trials (Itajaí, Turvo and Araranguá) during 2010 and 2011 growing season.

\begin{tabular}{ccccccc}
\hline & \multicolumn{2}{c}{ Itajaí } & \multicolumn{2}{c}{ Lontras } & \multicolumn{2}{c}{ Araranguá } \\
\cline { 2 - 7 } Varieties & $2015-16$ & $2016-17$ & $2015-16$ & $2016-17$ & $2015-16$ & $2016-17$ \\
\cline { 2 - 7 } & \multicolumn{7}{c}{${\mathrm{kg} \cdot \mathrm{ha}^{-1}}^{-1}$} \\
\cline { 2 - 7 } & 9063 & 9902 & 10,094 & 7656 & 12,930 & 11,452 \\
SCS123 Pérola & 672 & 7164 & 8564 & 4393 & 4545 & 9960 \\
"Carnaroli" & 2912 & 4063 & 3243 & 3840 & 3574 & 1617 \\
Empasc 104 & 7743 & 5057 & 7330 & 7456 & 7078 & 9099 \\
\hline
\end{tabular}

Table 4. Physical and chemical grain characteristics of rice cultivar SCS123 Pérola.

\begin{tabular}{|c|c|c|c|c|c|c|c|c|c|c|}
\hline \multirow{2}{*}{ Variety } & \multicolumn{3}{|c|}{ Milling yield (\%) } & \multirow{2}{*}{$\mathrm{AC}$} & \multirow{2}{*}{ GT } & \multicolumn{4}{|c|}{ Grain size $(\mathrm{mm})$} & \multirow{2}{*}{ Class } \\
\hline & Total & Whole & Broken & & & $\mathrm{L}$ & $\mathrm{W}$ & $\mathrm{T}$ & $\mathrm{L} / \mathrm{W}$ & \\
\hline $\begin{array}{l}\text { SCS123 } \\
\text { Pérola }\end{array}$ & 70.80 & 63.03 & 7.76 & 23.05 & $\mathrm{H}$ & 6.78 & 2.76 & 1.81 & 2.46 & Medium \\
\hline
\end{tabular}

Total: Percentage of total grain milled; Whole: Percentage of whole grain; Broken: Percentage of broken grain; AC: Percentage of amylose content; GT: Gelatinization temperature (H: height); L: Grain length; W: Grain width; T: Thickness and L/W: Length width ratio. 


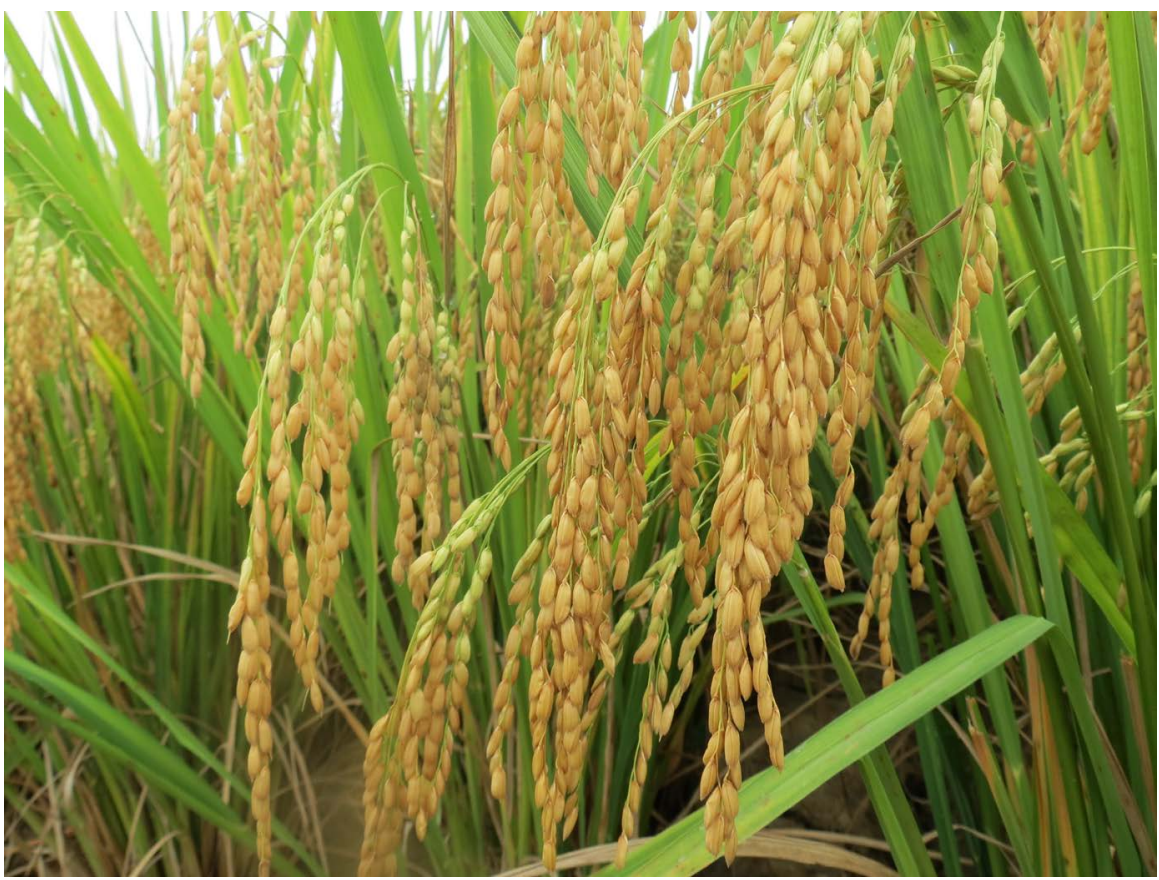

Figure 2. SCS123 Pérola panicle and grains.

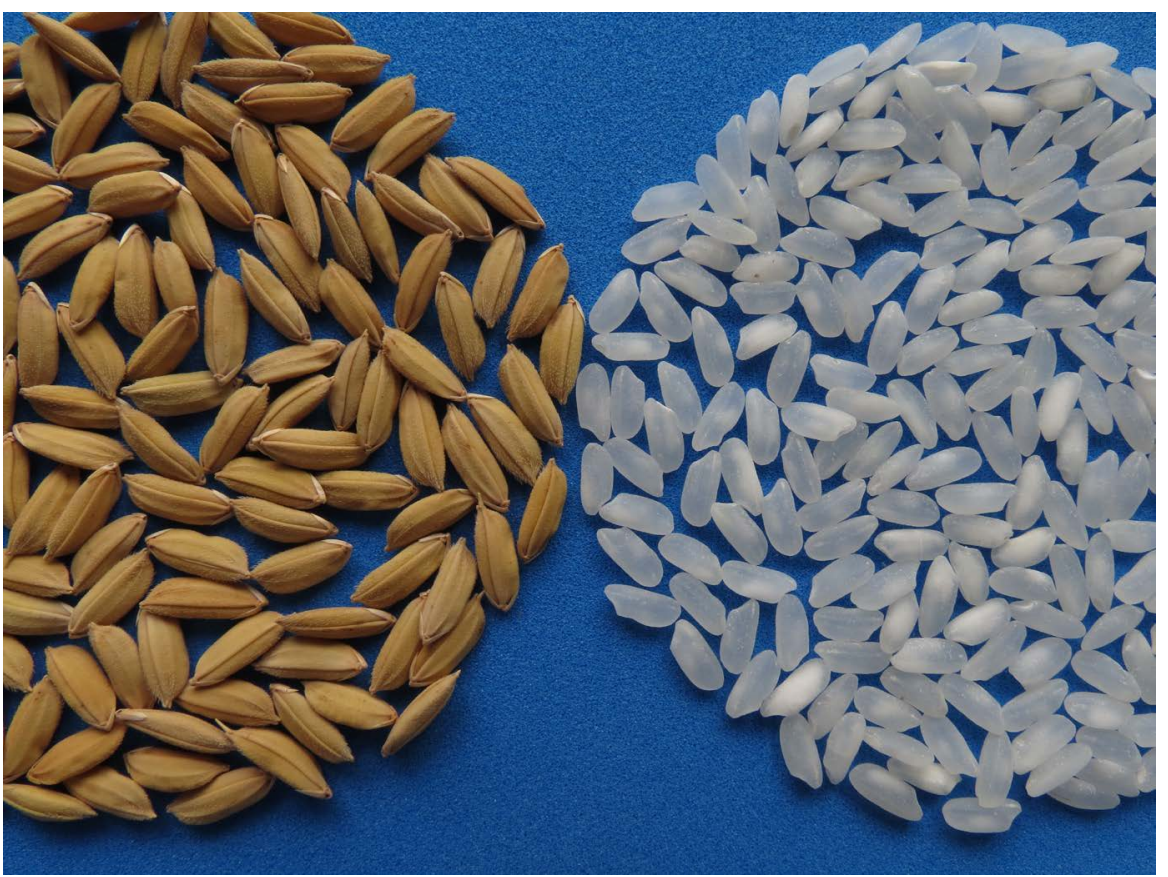

Figure 3. Aspects of SCS123 Pérola grains with hulls and milled.

soil and climate conditions of Santa Catarina for pigmented and aromatic grains and low amylose (grains for Japanese and Italian dishes). Therefore, cultivars originated from this project received names of precious stones. Previously, it was released cultivars SCS119 Rubi and SCS120 Ônix in allusion to its red and black grain pericarp color. For the same reason, SCS123 Pérola was named because of its rounded shape and white chalky color grain that look like a pearl. 


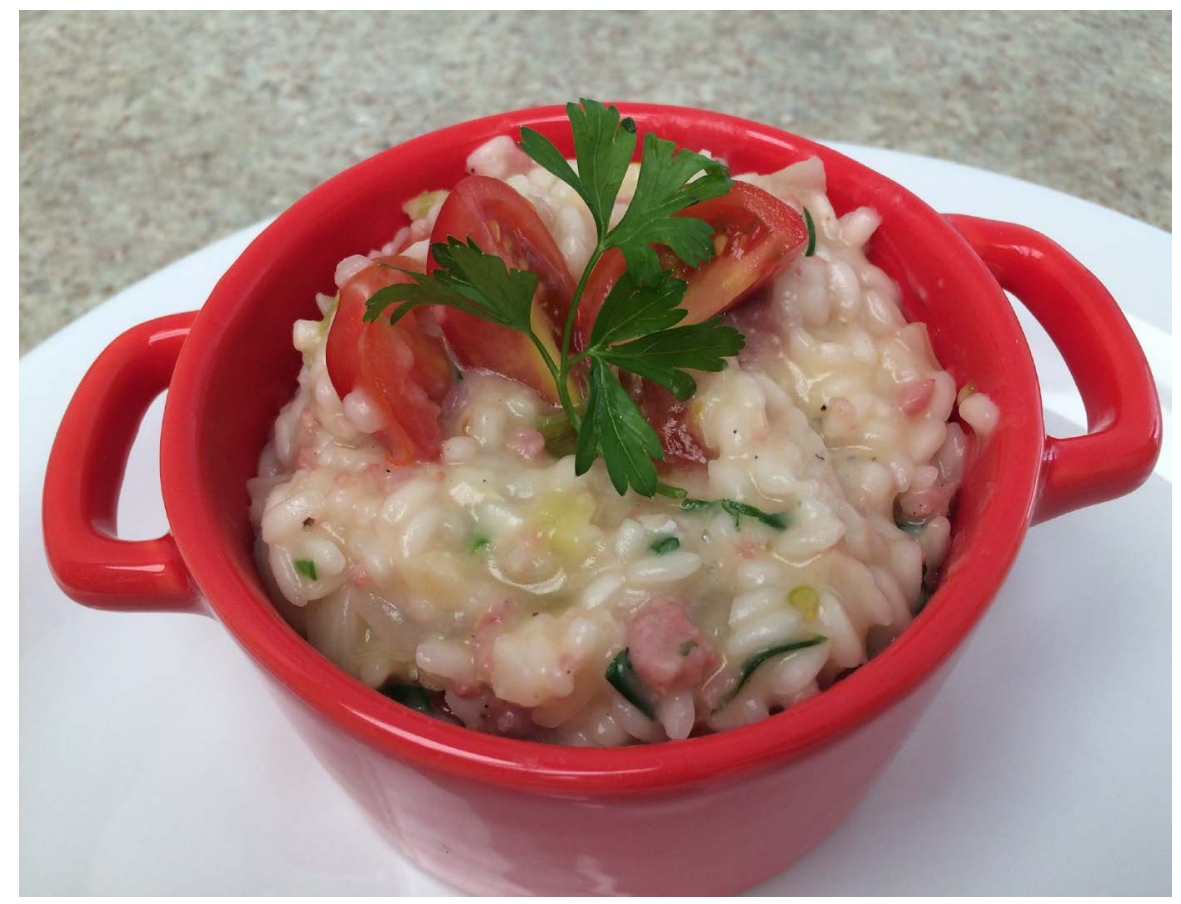

Figure 4. Risotto prepared with SCS123 Pérola.

Traditional rice varieties "Arborio" and "Carnaroli" are easily found in Brazilian markets and are well known and used by consumers for risotto. "Arborio" is the name of a short grain variety from Italy, characterized by having a very large kernel, and and a very high percentage of chalkiness that is characterized by the presence of white, opaque areas within the milled kernel, contrasting to the translucent whiteness of most varieties. "Carnaroli" is also originated from Italy, where is also used for risotto, differing from the more common 'Arborio' rice due to its higher starch content and hard texture, as well as having longer grains. "Carnaroli" rice keeps its grain shape better than other forms of rice during the slow cooking process required to prepare risotto due to its higher amylose content. It is the most widely used rice in the Italian cuisine and higher marked price [9]. Other rice varieties that are also found in the Brazilian market for the same purpose are "Roma" and "Vialone Nano".

Almost all risotto grains consumed in Brazil are imported from Italy and Argentina. Despite its grain quality, "Arborio" and "Carnaroli" varieties present plant type that is not well adapted to the Brazilian rice production systems. These traditional varieties presents higher plant height and exposed panicle, which causes lodge and birds damage. In contrast, SCS123 Pérola is a vigorous plant, with high tillering and erected leaves protecting grains. Therefore, these modern plant characteristic increased production significantly when compared to traditional varieties. This is an essential factor for helping small rice farmers to ensure adequate income.

SCS123 Pérola showed around thirty percent of grains with chalky area. Chalkiness is a heritable defect for milled rice and is one of the first parameters rice 
breeders consider in the selection process because it results in low milling yields and poor appearance. Chalkiness is also referred to as white belly and other names, depending on the position of the chalk in the milled kernel. But for "Arborio", chalkiness is associated with superior culinary properties for specific dishes, primarily risottos. Other than genetics, chalkiness is caused by high harvest moisture, uneven ripening, and management practices that result in uneven ripening and presence of immature kernels at harvest [9].

The SCS123 Pérola variety present the same quality grain for risotto compared to traditional and well known "Arborio" and "Carnaroli" grains, despite having a shape more similar to "Roma" variety. Risotto cooked with SCS123 Pérola grains is creamy, with good appearance, smell and taste.

Demand for specialty rices is increasing globally. The speciality rices are those which are not common, they are variable for amylose content, shape and size, endosperm color and aroma, making this characters important criterion to class a rice grain quality [10]. Production of rice varieties for high-value markets can increase the economic benefits to farmers and nutritional benefits to consumers [11].

All rice varieties developed and released by Epagri are registered and protected by MAPA. Variety registration assures the genetic identity and varietal quality by the breeding programs. Additionally, cultivar protection guarantees royalties to private and public breeding and seed companies, which can use these resources to support research and development projects [12]. Genotyping varieties is essential to identify and discriminate each variety one from another and to assure genetic purity on seeds production fields. Genotyping varieties are also used to protect intellectual properties.

Brazilian consumers had been interested in the diversification of foods sources, greatly because the media influence by cooking TV shows. This also happens to rice, helping to increase the percentage of consumers searching for specialty rices, creating (emerging) a high-value market for specialty rice grains (quality-added grains, like pigmented, aromatic and low-amylose content).

Santa Catarina has a peculiar characteristics related to landowners that produce rice grains is small properties $(5-10 \mathrm{ha})$ with family labor using high technology levels.

So, since 2002, Epagri's research team have carried out studies to offer to producers and consumers a portfolio of specialty rices covering varieties of pigmented pericarp (red and black), aromatic and glutinous types for specific market niches. As products associated to these special niches, specialty rice types have also higher market value, that in some case more than ten times the value of the traditional milled and parboilided rice.

\section{Seed Maintenance and Distribution}

Registration process of these new cultivars in the Ministry of Agriculture, Livestock and Food Supply-MAPA is an important step to assure seed production 
and commercialization in Brazil. Registration assures the genetic identity and varietal quality for the breeding programs.

The variety SCS123 Pérola is registered and protected in Brazil by the National Cultivar Registry (Registro Nacional de Cultivares-RNC) of the Ministry of Agriculture, Livestock and Supply under the number 37411 and 20170309, respectively. The genetic seed stock is kept by Epagri, at Itajaí Experiment Station.

\section{Conclusion}

The new rice variety SCS123 Pérola is considered suitable to be cultivated in all rice areas of Santa Catarina and consists in an alternative to help little farmers to be economically viable.

\section{Acknowledgements}

To the farmers who allowed to conduct experiments on their properties, as well as the technicians and extension people who contributed to the development of this new technology, our recognition; to Embrapa Rice and Beans (CNPAF), for the chemical analysis of the grains; to FAPESC (Fundação de Amparo a Pesquisa e Inovação do Estado de Santa Catarina) and CNPq (Conselho Nacional de Desenvolvimento Científico e Tecnológico) for the financial support.

\section{Conflicts of Interest}

The authors declare no conflicts of interest regarding the publication of this paper.

\section{References}

[1] Hori, K., Suzuki, K., Iijima, K. and Kaworu, E. (2016) Variation in Cooking and Eating Quality Traits in Japanese Rice Germplasm Accessions. Breeding Science, 66, 309-318. https://doi.org/10.1270/jsbbs.66.309

[2] Giraud, G. (2013) The World Market of Fragrant Rice, Main Issues and Perspectives. International Food and Agribusiness Management Review, 16, 1-20. https://prodinra.inra.fr/record/263732

[3] Gujral, H.S., Singh, J., Sodhi, N.S. and Singh, N. (2002) Effect of Milling Variables on the Degree of Milling of Unparboiled and Parboiled Rice. International Journal of Food Properties, 5, 193-204. https://doi.org/10.1081/JFP-120015601

[4] GRiSP (Global Rice Science Partnership) (2013) Rice Almanac. 4th Edition, International Rice Research Institute, Los Baños (Philippines), 283 p.

[5] Levy-Costa, R.B., Sichierib, R., Pontes, N.S. and Monteiro, C.A. (2005) Household Food Availability in Brazil: Distribution and Trends (1974-2003). Revista de Saúde Pública, 39, 1-10.

[6] Tuaño, A.P.P., Perez, L.M., Padolina, T.F. and Juliano, B.O. (2005) Survey of Grain Quality of Philippine Farmers' Specialty Rices. Philippines Agriculture Scientist, 98, 446-456.

[7] Bioversity International, IRRI and WARDA (2007) Descriptors for Wild and Cultivated Rice (Oryza spp.). Bioversity International, Rome, Italy; International Rice Research Institute, Los Baños, Philippines; WARDA, Africa Rice Center, Cotonou, Benin, 63 p. 
https://www.bioversityinternational.org/fileadmin/_migrated/uploads/tx_news/Rice 232.pdf

[8] Weising, K., Nybon, H., Wolff, K. and Kahl, G. (2005) DNA Fingerprint in Plants: Principles, Methods, and Applications. 2nd Edition, CRC Press Taylor \& Francis Group, Boca Raton, 444 p.

[9] The California Rice Research Board (2018) Variety Selection and Management. In: Rice Production Manual, 229 p. http://rice.ucanr.edu/files/288581.pdf

[10] Chaudhary, R.C. (2003) Speciality Rices of the World: Effect of WTO and IPR on Its Production Trend and Marketing. Food, Agriculture \& Environment, 1, 34-41.

[11] Magalhães Júnior, A.M., Franco, D.F., Fagundes, P.R.R., Morais, O.P., Pereira J.A., Cordeiro, A.C.C., Wickert, E., Moura Neto, F.P. and Severo, A.C.M. (2012) Indicação de Tipos Especiais de Arroz para Diversificação de Cultivo. Editora Embrapa, Pelotas, 8 p. (Circular Técnica, 133)

http://www.infoteca.cnptia.embrapa.br/handle/doc/954892

[12] Carvalho, S.I.C., Bianchetti, L.B. and Reifschneider, F.J.B. (2009) Registro e proteção de cultivares pelo setor público: A experiência do programa de melhoramento de Capsicum da Embrapa Hortaliças. Horticultura Brasileira, 27, 135-138.

https://doi.org/10.1590/S0102-05362009000200002 